Paper Number 02-3255

\title{
SURVEY OF STATE LAW ENFORCEMENT PERSONNEL ON WORK ZONE ENFORCEMENT PRACTICES
}

\author{
by \\ Steven D. Schrock \\ Graduate Assistant Researcher \\ Texas Transportation Institute \\ Texas A\&M University \\ 3135 TAMU \\ College Station, Texas 77843-3135 \\ Phone: (979) 845-1728 \\ Fax: (979) 845-6006 \\ E-mail: s-schrock@ttimail.tamu.edu \\ Gerald Ullman, Ph.D., P.E. \\ Program Manager \\ Texas Transportation Institute \\ Phone: (979) 845-1728 \\ E-mail: g-ullman@tamu.edu \\ Nada Trout \\ Assistant Research Scientist \\ Texas Transportation Institute \\ Phone: (979) 845-1728 \\ E-mail: n-trout@tamu.edu
}

Paper prepared for the $81^{\text {st }}$ Annual Meeting of the

Transportation Research Board

Washington D.C.

January 2002

\author{
Word Count \\ Abstract: 243 \\ Body: 4,065 \\ Tables: $1 \times 250=250$ \\ Figures: $4 \times 250=1,000$ \\ Total: 5,558
}




\title{
SURVEY OF STATE LAW ENFORCEMENT PERSONNEL ON WORK ZONE ENFORCEMENT PRACTICES
}

\begin{abstract}
An important first step in maximizing the effectiveness of law enforcement is to determine how officers currently operate in work zones. While transportation researchers may understand the benefits of different enforcement strategies, does this translate to improved enforcement methods in the field? A survey was developed and administered to determine the problems encountered by state law enforcement agencies across the country when enforcing work zones. The survey was also an attempt to identify areas of improvement and innovative practices worthy of further development.
\end{abstract}

State law enforcement agencies from 20 states were contacted by telephone to determine how work zones were enforced in their respective states. Officers were asked questions regarding:

- funding for work zone enforcement;

- techniques used by law enforcement at work zones;

- locations in or near work zones where officers are typically stationed;

- the level of coordination between law enforcement, the state highway authority, and the construction contractor; and

- initiatives that helped maximize the effectiveness of law enforcement in work zones.

One strategy identified in this research was the formation of specialized units to patrol work zones and to train other officers to effectively patrol work zones. A second strategy identified was a method to overcome the chronic shortage of available officers to patrol work zones. This strategy created a structure to allow local law enforcement agencies and retired officers the opportunity to be used in an overtime capacity to enforce work zones on state roadways. 


\section{INTRODUCTION}

One of the problems cited most commonly in high-volume, high-speed work zones is that traffic speeds are often excessive for roadway conditions. Some data exist to support this position. For example, studies of speed characteristics taken at a limited number of Texas work zones on interstate highways showed that 70 to 90 percent of the vehicles were exceeding the posted speed limit in the work zone (1). According to the Texas Department of Transportation (TxDOT), approximately 18 percent of all work zone accidents involve vehicles that were speeding. Other studies have suggested that excessive speeds contribute to work zone accidents $(2,3)$.

Drivers who travel significantly faster than the regular traffic stream approaching and passing through the work zone are a concern. This is true regardless of an appropriate reduced work zone posted speed. It is known that such speeding behavior significantly increases accident risk (4). Furthermore, this risk is most likely amplified by the presence of construction vehicles, increased traffic densities, and other characteristics inherent to work zones. These characteristics reduce available recovery time for errant vehicles. Just as importantly, higher speeds reduce the time available for workers to move out of the way of an errant vehicle that may intrude into the activity area.

Work zone enforcement is critical for maintaining safety and obtaining motorist compliance with traffic control regulations. However, due to the restrictive nature of a work zone (narrow lane widths, reduced number of lanes, work activity, etc.), it is often difficult for an officer to be effective. The research presented in this paper explores law enforcement personnel perspectives of how work zones can be improved to better support enforcement efforts. To accomplish this, a survey was developed and administered to determine the problems encountered by state law enforcement agencies across the country when enforcing work zones. Additionally, the survey was an attempt to identify areas of improvement and innovative practices worthy of further development.

\section{LITERATURE REVIEW}

Police enforcement at work zones has traditionally taken one of three forms: stationary, police traffic controller, or mobile (5). Stationary police enforcement consists of an officer positioned in a patrol car within the work zone, such as the merge area, activity area, or termination area. Police traffic controllers are stationary officers positioned outside of their vehicles directing traffic within the work zone. Mobile enforcement consists of one or more officers continuously circulating back and forth through the work zone.

Police enforcement has been shown to be an effective speed reduction technique in work zones. Studies have consistently shown the significant benefits of law enforcement presence, regardless of the method of enforcement used. Richards et al. examined the effectiveness of law enforcement for both stationary and mobile enforcement at six work zones in Texas in 1985, including rural and urban freeways, urban arterials, and rural two-lane highways (6). The study indicated that a stationary enforcement presence was able to reduce the mean speed of traffic by 5 to $12 \mathrm{mph}$. The researchers also found that police traffic controllers on an urban arterial or rural two-lane roadway were able to reduce speeds 9 to $14 \mathrm{mph}$. A circulating patrol car in the same study was found to reduce mean speeds by $2-3 \mathrm{mph}$ on a rural two-lane highway. 
Noel et al. conducted a similar study in 1987 on a six-lane freeway in Delaware. The researchers examined stationary officers in their patrol cars with lights and radar active, and with officers out of their vehicles acting as police traffic controllers. The study revealed that shortterm mean speeds for a one-lane closure were reduced by $2.4 \mathrm{mph}$ and 5.1, respectively for the two methods, and by $6.3 \mathrm{mph}$ for a two-lane closure for the police traffic controller. An unexpected mean speed increase of $3.6 \mathrm{mph}$ was reported for the first enforcement technique at a two-lane closure, with no reason stated.

Benekohal, Resende, and Orloski examined the speed reduction capabilities of police vehicles circulating through freeway work zones in rural Illinois (7). The research indicated that the mean speeds of vehicles were reduced by $4-5 \mathrm{mph}$ when officers were present. The study also examined the lasting speed-reduction effects on traffic after the enforcement leaves the work zone. One hour after the enforcement presence was removed the speed reduction in cars was negligible, while heavy trucks remained near the reduced speed, indicating at least some lasting effect from enforcement presence.

Previous research efforts indicate a speed-reduction benefit exists from the presence of law enforcement at work zones. However, a number of factors prevent extensive use of police at work zones, such as lack of available manpower or funding. Richards and Dudek found that the cost of hiring off-duty law officers for traffic control in Texas ranged from $\$ 10$ to $\$ 25$ per hour in 1983 (8). Using the "Inflation Calculator" at the U.S. Department of Labor, Bureau of Labor Statistic's homepage, this would correspond to a rate of from $\$ 17.87$ to $\$ 44.68$ per hour today (9). This high cost would most likely limit the use of enforcement at many work zones.

\section{INTERVIEW PROCEDURE}

State law enforcement agencies from 20 states were contacted by telephone to determine how work zones are enforced in their respective states. These states were selected at random, with care to ensure that a geographic variation and a population variation existed among those states selected. The states contacted are shown in Figure 1, and their respective agencies are listed in Table 1.

The agencies were contacted to determine the types of work zone enforcement found in these states, gain insight on the law enforcement officer's perspective regarding the methods used in work zone enforcement, and to identify innovative schemes for increasing the frequency and/or effectiveness of work zone enforcement. Typical contact persons included public relations officers, troop commanders, or troopers who actively patrol work zones. In a few cases, it was possible to speak directly with officers responsible for training other law enforcement officials in proper work zone enforcement.

Officers were asked questions regarding:

- funding for work zone enforcement;

- techniques used by law enforcement at work zones;

- locations in or near work zones where officers are typically stationed; 
- the level of coordination between law enforcement, the state highway authority, and the construction contractor; and

- initiatives that helped maximize the effectiveness of law enforcement in work zones.

\section{Interview Results}

The survey was administered by telephone using the questionnaire shown in the appendix. Due to the open structure of the questionnaire, officers were able to indicate multiple answers if more than one strategy or procedure was used in their state. As a result, the sum of the responses for some of the questions does not equal the sum of the total number of interviews.

\section{How is Work Zone Enforcement Funded?}

Officers were questioned about how officers were placed in work zones on state highways, such as if these were special assignments, overtime duty, or part of an officers regular shift.

- All 20 states (100 percent of those surveyed) use off-duty officers in an overtime capacity either totally or at least to supplement work zone enforcement. Five states volunteered that use of overtime was the only way that they were able to place officers in a work zone.

- Four states (20 percent of those surveyed) also indicated that some work zone enforcement activities are part of an officer's normal duty. In these cases, an officer might only be stationed at a work zone in 1-2 hour increments during the course of a shift. The majority of officers interviewed, however, indicated that they were usually "too busy" with their normal enforcement duties to patrol work zones significantly during their normal shift.

\section{Who Hires Officers for Overtime Enforcement?}

- Eleven states (55 percent of those surveyed) require the construction contractor to hire law enforcement officers as a subcontractor.

- Nine states (45 percent of those surveyed) indicate that their department of transportation (DOT) hires the law enforcement officers directly. In some cases this was for all work zones, and in some cases it was only to enforce DOT maintenance work zones.

\section{Where are Officers Positioned in a Work Zone?}

In order to determine the effectiveness of officers in work zones, the officers were asked where they positioned themselves in work zones in order to perform enforcement activities. Several respondents ( 20 percent of those surveyed) mentioned that they work with the contractor or department of transportation project inspector to determine the proper position to maximize safety to the workers. A summary of their responses is provided in the list below and in Figure 2.

- Thirteen states (65 percent of those surveyed) indicated that officers used stationary enforcement techniques, positioning themselves at various points in the work zone, such as at the upstream end or at the activity area. 
- Nine states (45 percent of those surveyed) indicated that circulating patrols were used on a regular basis. In two states, it was indicated that circulating patrols were used exclusively, with no stationary enforcement. Reasons given for relying on circulating techniques included the officers' sense that they were more effective if they were not fixed to a single location. This is interesting given the results of prior research which has showed the circulating patrol method to generally have a somewhat lower effect on mean speeds as compared to stationary patrol methods. This may illustrate that enforcement personnel and contractors or DOT personnel actually have different perspectives of what constitutes "effective" enforcement.

- Five states (25 percent of those surveyed) reported the use of police acting as traffic controllers outside their patrol cars. In these cases, this was the predominant enforcement activity of officers. This type of enforcement was most commonly mentioned from jurisdictions contacted in the Northeast. Interestingly, most other officers surveyed specifically mentioned that they were prohibited from acting as a police traffic controller for safety reasons.

- Four states (20 percent of those surveyed) reported regular patrol frequencies were increased in the area around the work zone in order to gain an increased presence in the work zone area.

- One state (5 percent of those surveyed) indicated that work zone enforcement was conducted "at the edges of the work zone." Officers spend their time in an area up to 5 miles prior to the beginning of the work zone. By patrolling this area, it was believed that the officers are more effective because they have more room to maneuver and apprehend violators.

What level of coordination exists between law enforcement, the state highway authority, and the construction contractor?

The officers were then asked about the level of coordination that exists between their state department of transportation, the construction contractor, and their enforcement agency regarding work zone enforcement. This question was asked to provide an indication of when law enforcement typically becomes involved in work zone activities. Listed below is a summary of the officers' comments. This is also summarized in Figure 3.

- Six officers (30 percent of those surveyed) indicated that their agency was involved at an early stage in the planning of the work zone traffic control. This included participation in joint task forces, which met monthly, yearly, or just for complicated work zones, depending on the state. Two of these officers also indicated that officers were also included in reviewing traffic control plans,

- Five officers (25 percent of those surveyed) indicated that their agency's involvement in work zone activities began with attendance at pre-construction meetings prior to the beginning of a specific project. In some instances, this included the post commander; in others, it was the patrol officer that would likely be stationed in the work zone.

- One officer (5 percent of those surveyed) stated that coordination took place directly between the district engineer responsible for the work zone and the enforcement agency's troop commander. 
- One officer (5 percent of those surveyed) indicated that their department of transportation handled all aspect of work zone enforcement through the establishment of a special program that hires officers directly for work zone enforcement.

- Seven officers (35 percent of those surveyed) reported that their agency either received no information about work zones, received minimal notice (a mailed announcement of an upcoming work zone), or were not sure if any coordination existed. In one instance, it was stated that it was the responsibility of the individual officer patrolling the work zone to make contact with the department of transportation and contractor personnel.

\section{What Strategies Maximize the Effectiveness of Work Zone Enforcement?}

The officers were asked about their experiences with work zone enforcement, and what in their opinion was the one strategy implemented in their state that made their officers most effective. The following list is a summary of their responses, which is also shown in Figure 4.

- The positive response most often stated (40 percent of those surveyed) by officers was that a highly visible enforcement officer and/or patrol car had the most positive impact on speed reduction. This was stated as a positive impact whether the officers were stationed outside of their vehicles as traffic controllers or if they were required to stay in their vehicles.

- Another desirable attribute often mentioned (30 percent of those surveyed) was an aggressive use of media campaigns. In the opinion of these officers, the media campaigns were generally helpful in getting motorists to comply with work zone speed limits. Several different types of media outlets were mentioned, including television news, radio news, and paid commercial advertisements by the highway patrols and department of transportation. Specifically mentioned were general warnings about the presence of work zones, public education about double fine laws, and specifics about a particular work zone, such as which ramps were open and which were closed, or the planned use of aerial enforcement.

- Only two officers (10 percent of those surveyed) considered their state's double fine laws to increase overall work zone enforcement effectiveness. A total of 18 (90 percent of those surveyed) of the states included in the survey had some form of a double fine law in effect at the time of this survey.

- Other methods mentioned by the officers included: using motorcycles to patrol work zones because they can maneuver through restricted spaces more easily, establishing liaisons with the DOT, increased staffing of enforcement at work zones, creating work zone pullout areas for officers, and the ability for an officer to remain mobile.

\section{SPECIAL WORK ZONE PROGRAMS}

In two states, special work zone enforcement programs were identified. The purpose of these special programs were to increase the effectiveness of work zone enforcement through better training or increased manpower availability to enforce work zones. Both of the special programs are briefly described. 


\section{South Dakota DOTCOP Speed Enforcement Program}

The DOTCOP program is a work zone speed enforcement program administered by the South Dakota Highway Patrol. This program allows officers to be placed at a work zone in an overtime capacity. A DOTCOP wears a distinct uniform and drives a distinct patrol car, which designates it as a work zone enforcement vehicle. These officers only have jurisdiction in and around the work zone area, and as a result, any arrest or other action which might require the DOTCOP to leave the work zone is beyond his/her powers. In such cases, another officer must be brought to the scene. The benefit to such a program is the DOTCOP must therefore stay at the work zone, and cannot be called away to address other enforcement needs at non-work zone locations.

This program had another unique feature not utilized by another state: any sworn officer or retired officer with a current firearm certification can become a DOTCOP. As a result, local police and even retired troopers may take part in the program, increasing the pool of potential manpower.

\section{New Jersey Division of State Police Construction Unit}

The state of New Jersey maintains a unit of 35 state police officers who are dedicated to work zone enforcement. These officers work approximately nine months of the year enforcing work zones and supervising other officers manning a work zone on an overtime basis. All coordination for placing officers at work zones is done by this unit. In addition, these officers are certified Occupational Safety Health Administration (OSHA) safety inspectors and are considered the main state safety inspector for highway work zones.

During the winter months, this unit conducts training of other officers to prepare them for work zone enforcement duty. DOT engineers also receive training from this unit, to gain a better understanding of work zone enforcement duties. This unit also reviews traffic control plans, attends work zone planning meetings, and works with contractors to ensure that the proper traffic control devices are present at work zones.

\section{DISCUSSIONS AND FINDINGS}

Cost will always be a factor in work zone enforcement. The high labor cost of providing a police officer presence means that work zone enforcement will likely continue to be intermittent at all but the most critical work zones. A need will therefore exist to improve the effectiveness of these officers when they are used in work zones.

Previous research studies have indicated that stationary enforcement and the use of police traffic controllers are the most effective method of slowing vehicles in work zones. However, this survey indicated that these strategies are not universally used in work zone enforcement, however. Some officers interviewed felt that stationary strategies were restrictive and counterproductive to their duty. There appears to be a discrepancy between what traffic engineers and law enforcement personnel think is "effective" work zone traffic enforcement. While traffic engineers want enforcement to reduce overall traffic speeds and to reduce crashes, officers appear to want the ability to remain mobile, or at least be able to easily move into the work zone traffic stream to stop violators. The development of pullout areas within a work zone 
for officers to safely stop violators without hindering the rest of the traffic stream could be one method to improve what both engineers and enforcement personnel think of as "effective" work zone traffic control.

Development of specialized programs within state department of transportation and state law enforcement agencies can make officers feel more effective. One strategy identified in this research was the formation of specialized units to patrol work zones and to train other officers to effectively patrol work zones. A second strategy identified was a method to overcome the chronic shortage of available officers to patrol work zones. This strategy created a structure to allow local law enforcement agencies and retired officers the opportunity to be used in an overtime capacity to enforce work zones on state roadways. The legal or jurisdictional issues that may impede the implementation of these strategies were not addressed in this research.

\section{ACKNOWLEDGEMENTS}

The Texas Department of Transportation, in cooperation with the Federal Highway Administration, U.S. Department of Transportation, sponsored this research. The contents of this paper reflect the views of the authors, who are responsible for the facts and accuracy of the data presented herein. The contents do not necessarily reflect the views of the Texas Department of Transportation or the Federal Highway Administration. 


\section{REFERENCES}

1. Ullman, G.L., P.J. Carlson, and N.D. Trout. Work Zone Traffic Legislation in Texas. Report FHWA/TX-99/1720-3. Texas Transportation Institute, March 1999.

2. Ha, T., and Z.A. Nemeth. Detailed Study of Accident Experience in Construction and Maintenance Zones. In Transportation Research Record 1509, TRB, National Research Council, Washington D.C., 1995, pp. 38-45.

3. Nemeth, Z.A., and D.J. Migletz. Accident Characteristics Before, During, and After Safety Upgrading Projects on Ohio's Rural Interstate Highway System. In Transportation Research Record 672, TRB, National Research Council, Washington D.C., 1978, pp. 19-24.

4. Jones, R.K., et al. Police Enforcement Procedures for Unsafe Driving Actions. Volume II: A Review of the Literature. Report DOT-HS-805-744. National Highway Traffic Safety Administration, December 1980.

5. Ullman, G.L., and D.R. Riesland. Catalog of Work Zone Speed Control Methods. Report FHWA/TX-90/1161-2. Texas Transportation Institute, May 1990.

6. Richards S.H., R.C. Wunderlich, and C.L. Dudek. Field Evaluation of Work Zone Speed Control Techniques. In Transportation Research Record 1035, TRB, National Research Council, Washington D.C., 1985, pp. 66-78.

7. Benekohal, R.F., P.T.V. Resende, and R.L. Orloski. Effects of Police Presence on Speed in a Highway Work Zone: Circulating Marked Police Car Experiment. Report FHWA-IL/UI240. University of Illinois, 1992.

8. Richards, S.H., and C.L. Dudek. Implementation of Work-Zone Speed Control Measures. In Transportation Research Record 1086, TRB, National Research Council, Washington D.C., 1986, pp. 36-42.

9. U.S. Department of Labor, Bureau of Labor Statistics. Consumer Price Indexes. July 18, 2001. http://stats.bls.gov/cpihome.htm, Accessed July 31, 2001. 


\section{APPENDIX: SURVEY QUESTIONNAIRE}

1. What funding mechanisms do you use to pay for work zone enforcement in your agency? What percentage of the time is each mechanism employed?

$\square$ Part of officer's normal duty

$\square$ Contractor contracts

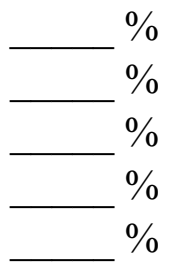

2. Some techniques used by law enforcement officials to patrol work zones are: (list from table below). Which of these techniques are used by your agency and what criteria are followed to implement each technique used? Check all that apply.

\begin{tabular}{||l||l||l||}
\hline \hline & \multicolumn{1}{|c||}{ Technique } & \multicolumn{1}{||}{ Criteria Followed } \\
\hline \hline & $\begin{array}{l}\text { Hiring of off-duty officers } \\
\text { dedicated to the work zone area. }\end{array}$ & \\
\hline & $\begin{array}{l}\text { Use of moving or circulating } \\
\text { patrols dedicated to the work } \\
\text { zone. }\end{array}$ & \\
\hline & $\begin{array}{l}\text { Increase circulating enforcement } \\
\text { patrol frequency by those who are } \\
\text { not dedicated to the work zone. }\end{array}$ & \\
\hline & $\begin{array}{l}\text { Station police vehicles upstream } \\
\text { of, or within, the work zone. }\end{array}$ & \\
\hline & $\begin{array}{l}\text { Use of police traffic controller } \\
\text { (uniformed officer upstream of } \\
\text { work zone). }\end{array}$ & \\
\hline & \begin{tabular}{l} 
Other: \\
\hline
\end{tabular} & \\
\hline
\end{tabular}


3. Have you parked your vehicle at: (name from list below) to perform your law enforcement duties? What advantages and/or disadvantages are there at each location identified?

\begin{tabular}{|l|l|l|l||}
\hline$\checkmark$ & \multicolumn{1}{|c|}{ Location } & \multicolumn{1}{c||}{ Advantages } \\
zone & $\begin{array}{l}\text { At the beginning of the work } \\
\text { construction workers are }\end{array}$ & \\
\hline $\begin{array}{l}\text { Inside the work zone away from } \\
\text { the construction workers }\end{array}$ & & \\
\hline At the end of the work zone & & \\
\hline Other (Please specify) & & \\
\hline
\end{tabular}

4. Are there any areas specifically designated by your state highway agency or contractors for accommodating law enforcement vehicles or uniformed officers within a work zone? NO $\square$ YES $\square \quad$ If yes, explain:

5. From your experience in the field, where do you consider to be the ideal location in the work zone for an officer to be positioned? Why?

$\square$ Sitting at the upstream end of a work zone

$\square$ Downstream end

$\square$ At the activity area

$\square$ Circulating

$\square$ Other, explain

6. What procedure(s) does your agency use to coordinate enforcement efforts with your state highway agency? Please briefly explain each method.

$\square$ None

$\square$ Joint task forces

$\square$ Attend Pre-construction meetings

$\square$ Attend ongoing meetings during construction

$\square$ Other, explain

7. What procedure(s) does your agency use to coordinate enforcement efforts with other local and/or state law enforcement agencies?

$\square$ None

$\square$ Joint task forces

$\square$ Other, explain 
8. What types of enforcement problems have you encountered while working in a work zone environment? Do you have any recommendation(s) on how to solve or improve this problem?

$\square$ Use old ticket book with no place to indicate the citation was issued in the work area

$\square$ “Worker's present" component of the double-fine law

$\square$ Safe vehicle placement within a work area

$\square$ Stopping vehicles within a work area

$\square$ Other, explain

9. Are there any initiatives or strategies used by your agency that you feel maximizes the effectiveness of work zone enforcement?

10. Do you have any suggestions on how state highway agencies can better accommodate law enforcement vehicles and/or personnel within the work zone area? NO $\square$ YES $\square$ If yes, explain:

11. What additional initiatives or strategies would you like to see implemented in your state that would further improve the effectiveness of work zone enforcement, if any? Please explain your thoughts.

12. Are there any types of legislation on law enforcement in the work zone area that you would like to see enacted in your state? NO $\square$ YES $\square$ If yes, explain: 


\section{LIST OF TABLES AND FIGURES}

Table 1: Agencies Contacted for this Survey

Figure 1: States Contacted for this Survey

16

Figure 2: Techniques used to Patrol Work Zones

Figure 3: When Law Enforcement and State Department of Transportation Begin Coordination

Figure 4: Techniques that Officers Believe Increase Enforcement Effectiveness in Work Zones 
Table 1: Agencies Contacted for this Survey

\begin{tabular}{|l|l|}
\hline \multicolumn{2}{|c|}{ State Law Enforcement Agencies Contacted } \\
\hline California & California Highway Patrol \\
Colorado & Colorado State Patrol \\
Connecticut & Connecticut State Police \\
Delaware & Delaware State Police \\
Florida & Florida Highway Patrol \\
Illinois & Illinois Highway Patrol \\
Iowa & Iowa Highway Patrol \\
Kansas & Kansas Highway Patrol \\
Maryland & Maryland Department of Police \\
Massachusetts & Massachusetts State Police \\
Michigan & Michigan State Police \\
Minnesota & Minnesota State Highway Patrol \\
Missouri & Missouri State Highway Patrol \\
New Jersey & New Jersey Division of State Police \\
Ohio & Ohio Department of Safety \\
Oregon & Oregon Highway Patrol \\
Pennsylvania & Pennsylvania State Police \\
South Dakota & South Dakota Highway Patrol \\
Utah & Utah Highway Patrol \\
Wisconsin & Wisconsin Highway Patrol \\
\hline
\end{tabular}




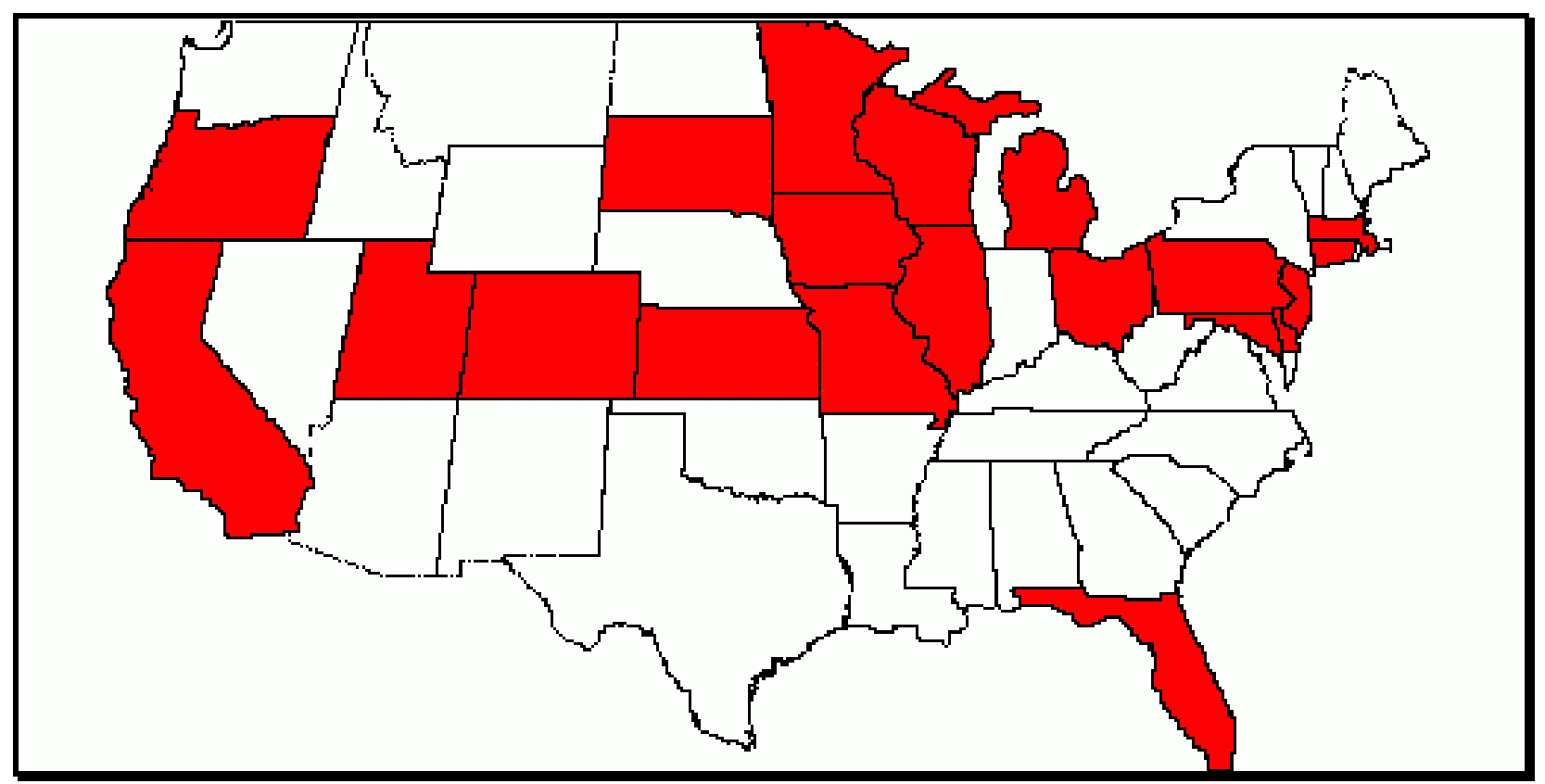

Figure 1: States Contacted for this Survey 


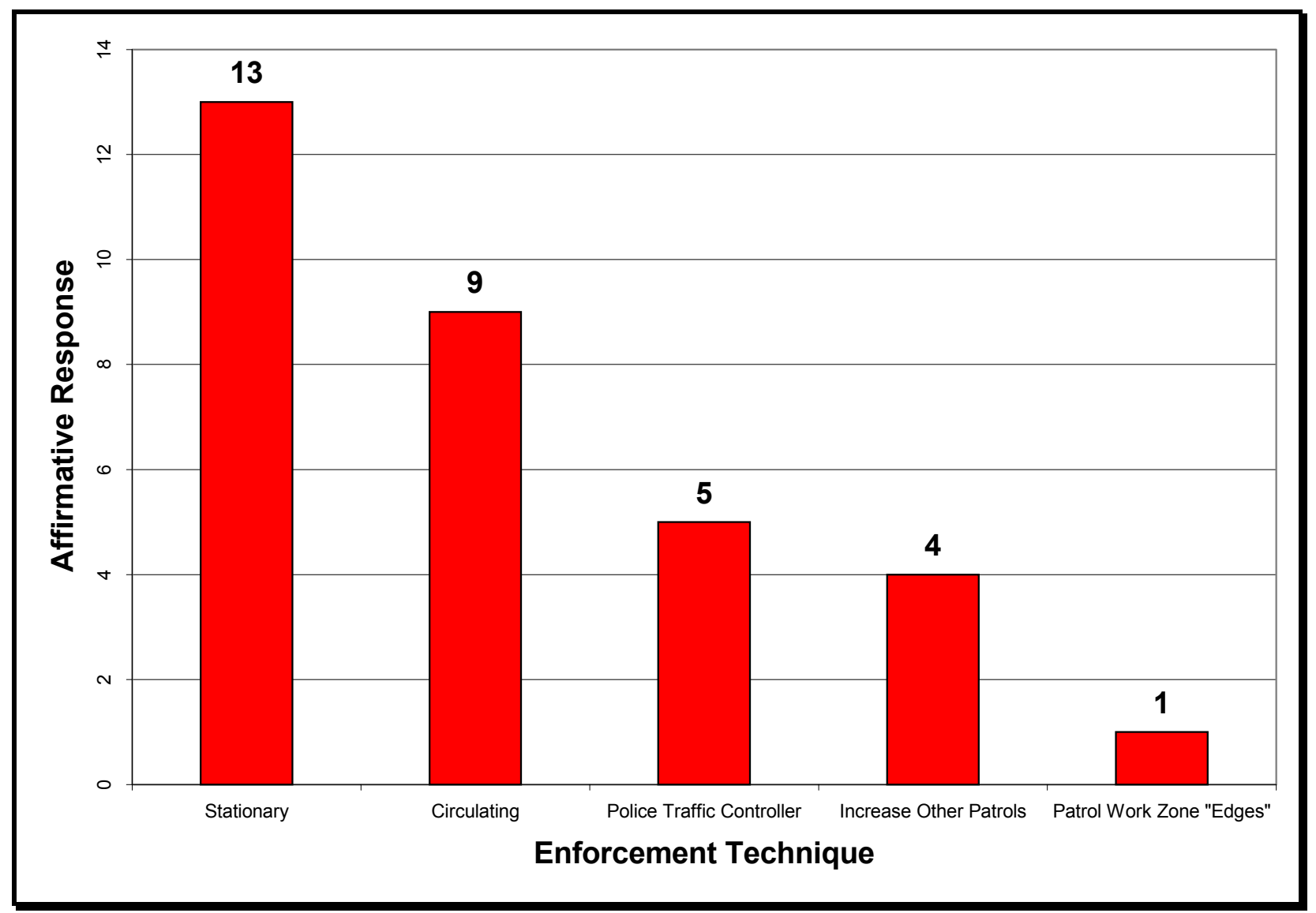

Figure 2: Techniques used to Patrol Work Zones 


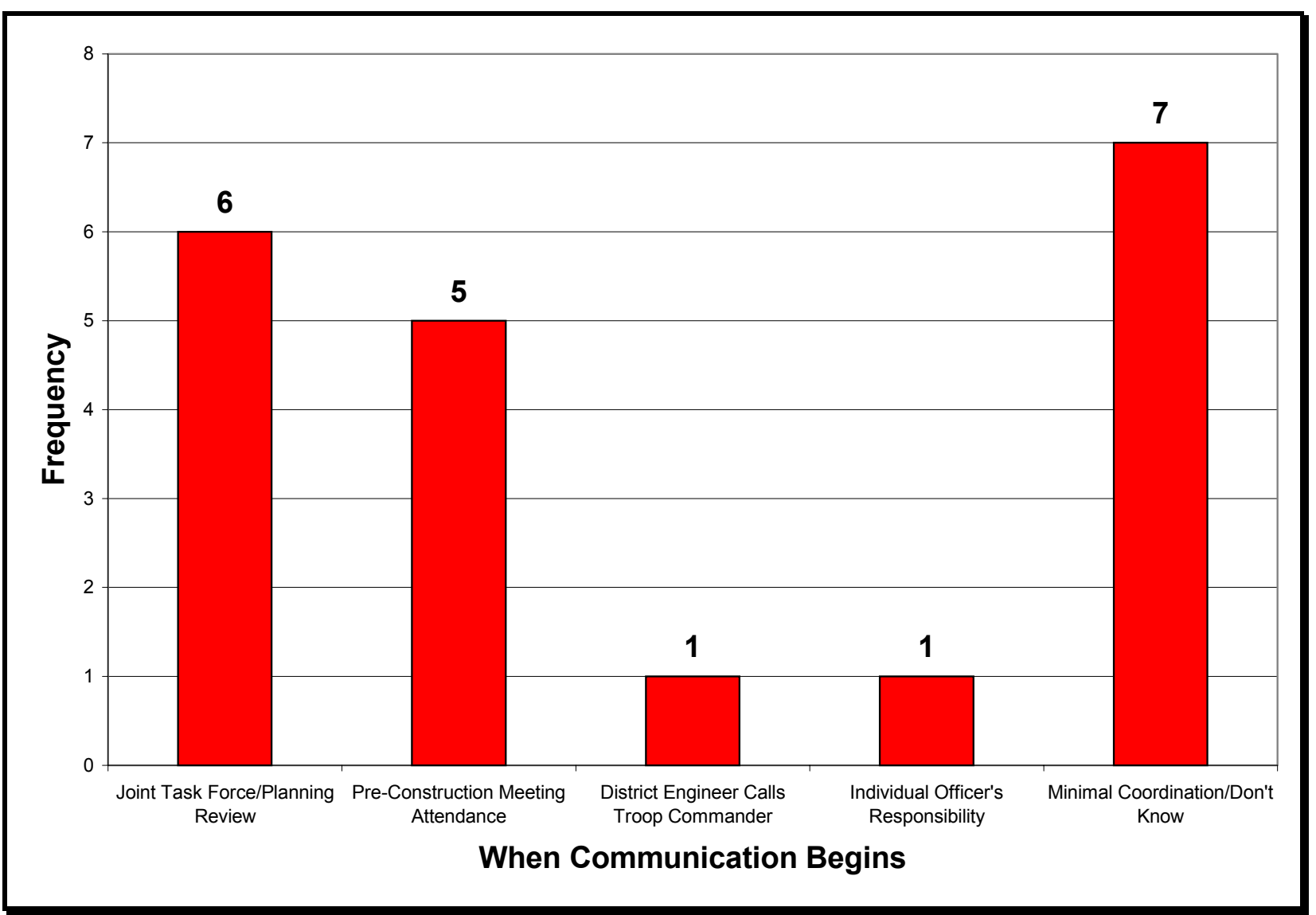

Figure 3: When Law Enforcement and State Department of Transportation Begin Coordination 


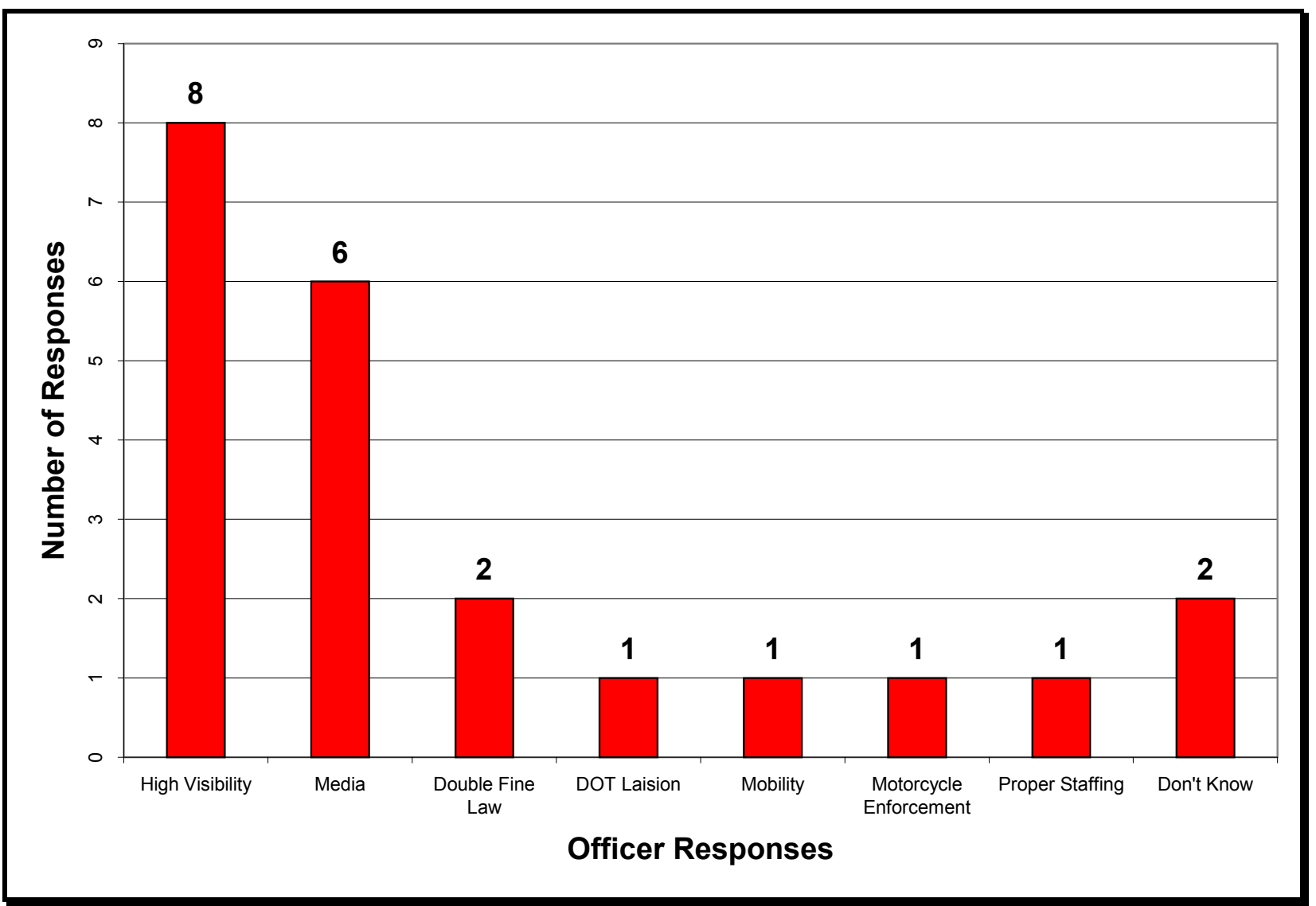

Figure 4: Techniques that Officers Believe Increase Enforcement Effectiveness in Work Zones 